\title{
Global Academic Journal of Pharmacy and Drug Research
}

Available online at https://www.gajrc.com

DOI: $10.36348 /$ gajpdr.2021.v03i02.001

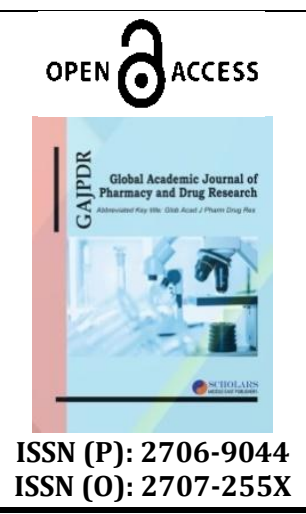

Original Research Article

\section{Effect of substituted N-(4-methyl-2-oxo-2H-chromen-7-yl) benzamide in Alloxan Induced Diabetic Rat}

\author{
Harsha M. Naikwad ${ }^{1}$, Neelakanth M. Jeedi1 ${ }^{*}$, Pradeepkumar Ronad ${ }^{2}$ \\ ${ }^{1}$ Department of Pharmacology, K L E College of Pharmacy, Vidyanagar, Hubballi-580031, (A constituent unit of KLE Academy of Higher \\ Education and Research, Belagavi), Karnataka, India \\ 2Department of Pharmaceutical Chemistry, K L E College of Pharmacy, Vidyanagar, Hubballi-580031, (A constituent unit of KLE Academy of \\ Higher Education and Research, Belagavi), Karnataka, India
}

\section{*Corresponding Author \\ Neelakanth M. Jeedi}

\section{Article History}

Received: 19.05 .2021

Accepted: 23.06.2021

Published: 30.06 .2021

\begin{abstract}
Coumarin compounds own different type of biological activities like antimicrobial, anti-inflammatory and anti-diabetic. The present study undertaken to investigate anti-diabetic activity of new synthetic coumarin derivatives in alloxaninstigated diabetic rats. Effect of coumarins on normal rats studied. Diabetes persuade in Wistar rats by injecting alloxan hydrate $(150 \mathrm{mg} / \mathrm{kg}$, body weight $)$ once. Normoglycemic and hyperglycemic rats separated into different groups. Animals treated with coumarins \& Metformin $(100 \mathrm{mg} / \mathrm{kg})$ as a reference drug for a period of 21 days. Antidiabetic activity assessed by measuring blood glucose, insulin, lipid profile, total proteins and calcium. Coumarin derivatives $(200 \mathrm{mg} / \mathrm{kg})$ treatment for 21 days exhibited very little anti-diabetic activity as compared with the standard drug metformin $(100 \mathrm{mg} / \mathrm{kg})$ treatment. Alloxan made diabetic rats treated with coumarins $(200 \mathrm{mg} / \mathrm{kg})$ showed nonsignificant reduction in serum glucose, total cholesterol, triglycerides, but serum HDLcholesterol, total proteins and calcium were significantly decreased. Coumarin derivatives do not possess effective anti-diabetic property. Because, treatment with these synthetic compounds there is no significant reduction in blood glucose level and lipid profile not corrected and slightly increase in the level of serum protein and calcium seen in alloxan induced diabetic rats.

Keywords: Coumarin derivatives, Alloxan, Metformin, Diabetes
\end{abstract}

Copyright (C) 2021 The Author(s): This is an open-access article distributed under the terms of the Creative Commons Attribution 4.0 International License (CC BY-NC 4.0) which permits unrestricted use, distribution, and reproduction in any medium for non-commercial use provided the original author and source are credited.

\section{INTRODUCTION}

Diabetes Mellitus (DM) is due to disorganization of metabolism, characterized by high glucose level in blood. Metabolic disorder is as a result of absolute shortage or lack of insulin to act on target tissues [1]. DM has two categories: Type 1 in this insufficiency of insulin because of autoimmune antibodies damaging beta cells of pancreas. In Type 2 normal insulin level but tissues developed resistance to it or less insulin secretion. Normally Type 2 individuals are habitually overweight [2]. As a result of high levels of glucose in blood for long duration that causes small and large blood vessels abnormalities. The abnormality in lipid metabolism leads to hyperlipidemia, it is marked by high cholesterol, triglycerides and altered lipoprotein levels [3]. These abnormalities are main cause for illness and death in DM. Africa's-International Diabetes Federation reports more than 1.4 crore people suffering with DM in their country, and they predicted number of patient rise to 2.8 crore by the year 2040. That attributes significantly to the global health burden and a major contributor for the global health afflicting 285 million adult populations and expected to accelerate to 439 million by 2030 . Annually, about 1.5 million deaths reported worldwide due to diabetes. As per World Health Organization (WHO) report in India alone nearly 
about 31 million people suffered with diabetes in the year 2000. In future it may to grow up to 79 million by 2030 [4]. Oral hypoglycemic agents used to treat DM causes different side effects like hematological effects and affects the functions of vital organs like liver and kidney. In addition, there is no perpetual cure for diabetic neuropathy however; symptomatic treatments have shown limited success.

Animals can be made diabetic by injecting Alloxan or Streptozotocin (STZ) that resembles natural DM. STZ damaging pancreatic beta cells by producing free radicals and acting on chromosomes. This causes suppression of insulin production and its release [5]. Chemically alloxan is Pyrimidine$2,4,5,6(1 \mathrm{H}, 3 \mathrm{H})$-tetraone hydrate. Alloxan causes lipid peroxidation and breaks DNA. It causes high blood glucose level and glycosuria in several species of animals.

Coumarins (1-benzopyran-2-one) are chemical compounds in the benzopyrone group of organic compounds established in many plants. Schiff base are the nitrogen analogue of aldehyde and ketone which contain $\mathrm{C}=\mathrm{N}-\mathrm{R}$ group coumarins own different type of biological properties, including antimicrobial [6], antiviral [7], anti-inflammatory [8], and anti-diabetic [9]. Many synthetic coumarin derivative compounds ex. scopoletin are proved for their anti-diabetic activity [10].
New synthetic compounds for treating diabetes are a research for safer alternatives to presently used anti-diabetic drugs. Coumarins are metabolites present in plants and are mainly used as anti-coagulation \& anti-thrombotic agents also for heart blood vessels diseases. By considering relation between diabetes and cardiovascular diseases, Coumarins would be more valuable if they were also effective in diabetes. Hypothetically, they lower blood sugar levels, equally improve cardiac complications. Plant material with coumarins has anti-diabetic property [11-13]. Natural Coumarin [14-16] and Coumarin derivatives [7,8], umbelliferon [17], esculentin [18] reported is useful for diabetes and its complications and antiinflammatory and oxidative protection. This encouraging review makes us to select these compounds for this research. Physical data of substituted N-(4-methyl-2-oxo-2H-chromen-7-yl) benzamide (IV e, $\mathrm{c}$ and $\mathrm{j}$ ) [19]:

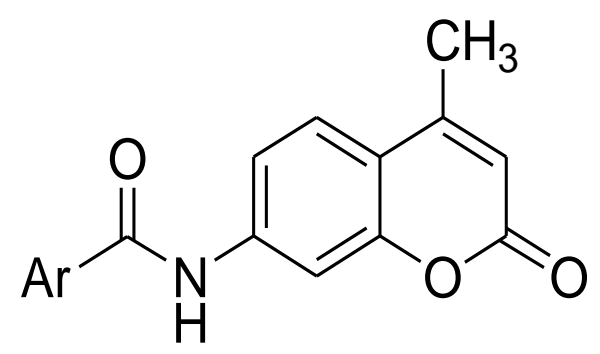

\begin{tabular}{|c|c|c|c|c|c|c|c|c|}
\hline \multirow{2}{*}{ Compound } & \multirow{2}{*}{ Ar } & \multirow{2}{*}{$\begin{array}{l}\% \\
\text { Yield }\end{array}$} & \multirow{2}{*}{$\begin{array}{l}\text { Melting } \\
\text { Point }^{\mathrm{a}}\end{array}$} & \multirow{2}{*}{$\begin{array}{l}\text { Rf } \\
\text { Value }^{b}\end{array}$} & \multirow{2}{*}{$\begin{array}{l}\text { Mol. } \\
\text { Formula }\end{array}$} & \multicolumn{3}{|c|}{ Found (cal.) \% } \\
\hline & & & & & & $\mathrm{C}$ & $\mathbf{H}$ & $\mathbf{N}$ \\
\hline IV c & $4-\mathrm{C}_{6} \mathrm{H}_{4} \mathrm{Cl}$ & 92.6 & $197-198$ & 0.89 & $\mathrm{C}_{16} \mathrm{H}_{10} \mathrm{NClO}_{3}$ & $\begin{array}{l}64.11 \\
(64.12)\end{array}$ & $\begin{array}{l}3.37 \\
(3.36)\end{array}$ & $\begin{array}{l}4.64 \\
(4.67)\end{array}$ \\
\hline IV e & $\begin{array}{l}4- \\
\mathrm{C}_{6} \mathrm{H}_{4} \mathrm{CH}_{3}\end{array}$ & 92.0 & $270-272$ & 0.31 & $\mathrm{C}_{17} \mathrm{H}_{13} \mathrm{NO}_{3}$ & $\begin{array}{l}73.09 \\
(73.11)\end{array}$ & $\begin{array}{l}4.65 \\
(4.69) \\
\end{array}$ & $\begin{array}{l}5.19 \\
(5.01) \\
\end{array}$ \\
\hline $\mathrm{IV} \mathrm{j}$ & $4-\mathrm{C}_{5} \mathrm{H}_{5} \mathrm{~N}$ & 81.7 & $>320$ & 0.62 & $\mathrm{C}_{15} \mathrm{H}_{10} \mathrm{~N}_{2} \mathrm{O}_{3}$ & $\begin{array}{l}67.68 \\
(67.67)\end{array}$ & $\begin{array}{l}3.80 \\
(3.79)\end{array}$ & $\begin{array}{l}10.48 \\
(10.53)\end{array}$ \\
\hline
\end{tabular}

\section{MATERIALS AND METHODS Animals}

Albino Wistar rats (150-250gm) of both sexes, housed in clean cages and maintained under the natural light \& dark. Standardized laboratory food and water ad libitum given to animals. Animals acclimatized for one week before experiment. Rats randomly selected for different experimental groups after seven days of acclimatization. The experimental protocol proposal No. MPH 02/KLECOPH/19 has been reviewed and approved on 11.11.19 by CPCSEA nominee and chairman IAEC, KLE College of Pharmacy, Hubballi. Karnataka.

\section{Coumarin derivatives}

Coumarin derivatives collected were synthesized by Dr. Pradeep Ronad, department of pharmaceutical chemistry, KLE college of Pharmacy,
Hubballi. Suspension of test compounds made by mixing with $0.3 \% \mathrm{w} / \mathrm{v}$ a sodium carboxy-methyl cellulose using distills water [20].

\section{Chemicals}

Alloxan hydrate, commercial diagnostic kits required to estimate biochemical's like lipid profile, enzymes level etc. purchased from local vendors of Erba Diagnostic Pvt. Ltd. The drug MFM procured from KLE college of Pharmacy, Hubballi. Metformin suspension was prepared with $0.3 \% \mathrm{w} / \mathrm{v}$ sodium carboxyl methylcellulose in distilled water. Analytical grade chemicals purchased by local vendors at Hubballi, Karnataka, India.

\section{Acute Oral Toxicity Study}

Acute oral toxicity study was done to decide safest dose according OECD guidelines No. 423; 
(annexure-2d) of CPCSEA, Ministry of Environment, Govt. of India, New Delhi. Test performed on albino mice weighing between 25-30 gm. The step-wise Up - Down method selected for toxicity studies. Female mice were starved full night and randomly separated in six groups $(n=3)$ they were orally treated with coumarins at a dose levels $100 \mathrm{mg} / \mathrm{kg}$, $500 \mathrm{mg} / \mathrm{kg}, 1 \mathrm{gm} / \mathrm{kg}$ and $2 \mathrm{gm} / \mathrm{kg}$ body weight by using stomach tube. The animals individually observed at least once during 30 minutes to indicate compound-related toxicity and mortality, periodically for the first 24 hours, with special attention for 4 hours.

\section{Induction of Diabetes}

Diabetic condition practically made in the rats of groups 2-5. The overnight fasted rats injected alloxan hydrate $(150 \mathrm{mg} / \mathrm{kg})$ dissolved in normal saline by subcutaneous route. After 3 days, induction confirmed by measuring blood glucose, if it is above $250 \mathrm{mg} / \mathrm{dl}$ considered as diabetic and included in study [21].

\section{Experimental Design}

Individually weighed animals randomly allotted to five groups, animals six in each group. Group one non-diabetic and remaining four diabetic groups receive various treatments as mentioned below. Equal number of male and females were maintained in each group and caged separately (3 rats per cages) throughout the experimental period.

\section{Groups}

Group 1: Control group animals receive $0.5 \mathrm{ml}$ of vehicle, $0.3 \% \mathrm{w} / \mathrm{v}$ sodium carboxyl methylcellulose in distilled water. Group 2: Alloxan (150 mg/kg) induced diabetes. Group 3: Alloxan induced diabetes treated with synthetic compound 1, p-Chloro-N-(4-methyl-2-oxo-2H-chromen-7-yl) benzamide (IVc) $(200 \mathrm{mg} / \mathrm{kg})$. Group 4: Alloxan induced diabetes treated with synthetic compound 2, p-Methyl-N-(4-methyl-2-oxo-2H-chromen-7-yl) benzamide (IVe) $(200 \mathrm{mg} / \mathrm{kg})$. Group 5: Alloxan induced diabetes treated with synthetic compound 3, N-(4-methyl-2-oxo-2H-chromen-7-yl) isonicotinamide (200 mg/kg). Group 6: Alloxan induced diabetes treated with standard drugmetformin (100mg/kg) [22].

The vehicle, MFM and coumarin compounds solutions administered to the respective group of animals by oral gavages, one time in a day for three weeks. Rats are fasted for 16 hours; blood collected retro-orbitally using capillary tube under mild ether anesthesia. Blood allowed clots for 10 minutes, serum alienated after 10 minutes centrifuging at $5000 \mathrm{rpm}$ and used for study. To assess antidiabetic activity various biochemical parameters measured using blood. The animals streamlined after cervical dislocation on the twenty-first day. Blood glucose estimated in all groups, before and after treatment on $1^{\text {st }}, 3^{\text {rd }}, 7^{\text {th }}, 14^{\text {th }}$ and $21^{\text {st }}$ day after the respective treatment. After twenty one days drug administration period, the animals were subjected to overnight fasting; blood taken and tested for glucose, insulin, total cholesterol (TC), total protein, triglycerides (TG), High-density lipoprotein (HDL) and calcium in all the groups [23-28]. In addition to the above body weight also measured. Blood glucose measured by Trinders method [29]. Insulin measured by enzyme linked immunosorbent assay. TC measured by enzymatic colorimetric (chod-pap) method [30]. TG estimated by method of McGowan et al., and Fossati et al. [31,32], HDL-cholesterol by enzymatic colorimetric method [33]. Total protein measured by Biuret Method [34]. Serum calcium measured by using ligand Arsenazo III in an aqueous alkaline medium [35]. All these biochemical measured using standard kit from ERBA and semiAutoanalyser.

\section{DATA ANALYSIS}

Data obtained furnished as the Mean \pm S.E.M (standard error of mean). Statistical analysis done by one-way analysis of variance (ANOVA), then subsequently by Tukey's multiple evaluation tests. Significance expressed by $p$ values and if $p$ value is $<0.05$, the results were regarded as statistically significant.

\section{RESULTS AND DISCUSSION Acute oral toxicity study}

In the acute oral toxicity (LD50) study, observed that no death or severe side effects were observed due to coumarin compounds at a dose of $2000 \mathrm{mg} / \mathrm{kg}$. Therefore, 1/10 of dose for coumarin derivatives (200 mg / kg) were considered as effective doses in this study.

\section{Effect of coumarin compounds on body weight of rats}

Prior to treatment, the body weight of all animals were normal. On the first day, the body weight of normal animals was slightly increased, but diabetic animals showed decreased, compare to its mean value before treatment. Treatment with three synthetic compounds does not shown any sign of increasing in body weight compared to its mean value before treatment. On the Third day, the body weight of normal control group animals further slightly increases. The diabetic control and coumarin compounds treatment animals showed further slight decrease in body weight compared to first day. All three coumarin compounds had not shown any sign of increasing in body weight. On seventy day, the normal animals body weight continued to increase slightly, but diabetic control and animals treated with coumarin compounds were significantly 
$(\mathrm{p}<0.05)$ decreased compared to its mean value before treatment. On fourteenth day continuation of increase and decrease in body weight of normal and diabetic animals were observed respectively. Coumarins derivative treatment group animals continued to lose body weight significantly $(\mathrm{p}<0.01)$. On twenty-one day continuation of increase and decrease in body weight of normal control and diabetic control group animals were observed respectively. And all three coumarins derivative continued to lose their body weight significantly $(\mathrm{p}<0.001)$ compared to mean value before treatment. All values depicted in Table 1.

Table-1: Effect of coumarin derivatives on Body Weight (g) in experimental rats

\begin{tabular}{|l|l|l|l|l|l|l|}
\hline Treatment & Control & $\begin{array}{l}\text { Diabetic } \\
\text { control }\end{array}$ & Compound I & $\begin{array}{l}\text { Compound } \\
\text { II }\end{array}$ & $\begin{array}{l}\text { Compound } \\
\text { III }\end{array}$ & $\begin{array}{l}\text { MFM 100 } \\
\text { mg/kg }\end{array}$ \\
\hline $\begin{array}{l}\text { Before } \\
\text { treatment }\end{array}$ & $180.2 \pm 2.0$ & $180.21 \pm 0.1$ & $190.12 \pm 2.2$ & $195.12 \pm 2.1$ & $180.11 \pm 2.3$ & $182.45 \pm 2.3$ \\
\hline $\begin{array}{l}\text { After } \\
\text { treatment } \\
\text { 1st day }\end{array}$ & $185.23 \pm 2.1$ & $178.27 \pm 4.4^{\mathrm{ns}}$ & $178.21 \pm 4.1^{\mathrm{ns}}$ & $171.11 \pm 2.2^{\mathrm{ns}}$ & $168.21 \pm 3.2^{\mathrm{ns}}$ & $170.21 \pm 3.3^{\mathrm{ns}}$ \\
\hline 3rd day & $189.23 \pm 1.7$ & $162.1 \pm 3.9^{\mathrm{ns}}$ & $162.45 \pm 3.1^{\mathrm{ns}}$ & $165.24 \pm 2.4^{\mathrm{ns}}$ & $155.34 \pm 2.2^{\mathrm{ns}}$ & $175.23 \pm 2.2^{\mathrm{ns}}$ \\
\hline 7th day & $195.34 \pm 3.3$ & $151.24 \pm 3.6^{*}$ & $155.37 \pm 2.2^{*}$ & $150.21 \pm 3.3^{*}$ & $143.41 \pm 1.5^{*}$ & $181.11 \pm 2.5^{*}$ \\
\hline 14th day & $201.14 \pm 2.4$ & $142.41 \pm 3.2$ & $142.2 \pm 3.4^{* *}$ & $141.4 \pm 1.3^{* * *}$ & $138.24 \pm 3.3^{* *}$ & $185.41 \pm 3.1^{* * *}$ \\
\hline 21th day & $204.53 \pm 2.4$ & $130.15 \pm 2.3$ & $135 \pm 3.1^{* * *}$ & $134.3 \pm 2.3^{* * *}$ & $130.1 \pm 4.1^{* * *}$ & $188.21 \pm 3.3^{* * *}$ \\
\hline
\end{tabular}

Values presented as Mean \pm SEM $(n=6)$. MFM-Metformin, $p<0.05^{*}, p<0.01^{* *}, p<0.001^{* * *}$, ns -non significant. After treatment compared with mean values before treatment of respective groups.

\section{Effect of coumarin derivatives on blood glucose in Alloxan-persuaded diabetic rats}

Prior to induction of diabetes the FBG level in all the group animals were normal. After induction of diabetes to all group animals except normal control, FBG level was significantly $(\mathrm{p}<0.001)$ very high. After induction, FBG of normal control animals was normal, but diabetic induced animals were significantly high $(\mathrm{p}<0.001)$ compared to its mean value before induction. During treatment period that is on third, seventh, fourteenth and twenty first days, it is observed that there is no significant changes occurred in FBG of normal control animals. From the day one to day twenty one there is consistent increase in FBG of diabetic control animals was observed. Whereas, coumarins derivatives treated animals showed only slight and continuous decrease in FBG but not significant compared to mean values of day one of treatment of respective groups. Standard drug MFM $100 \mathrm{mg} / \mathrm{kg}$ treatment reduces significantly the FBG from day one to day twenty one. At the end of MFM treatment period the FBG of treated animals were almost near to before induction of diabetes. All values depicted in Table 2.

Table-2: Effect of Coumarin derivatives on blood glucose level (mg/dl) in control and experimental rats

\begin{tabular}{|l|l|l|l|l|l|l|}
\hline Treatment & Control & $\begin{array}{l}\text { Diabetic } \\
\text { control }\end{array}$ & Compound I & $\begin{array}{l}\text { Compound } \\
\text { II }\end{array}$ & $\begin{array}{l}\text { Compound } \\
\text { III }\end{array}$ & $\begin{array}{l}\text { MFM 100 } \\
\text { mg/kg }\end{array}$ \\
\hline Before induction & $78 \pm 1.2$ & $81 \pm 1.1$ & $83 \pm 1.5$ & $81 \pm 0.8$ & $80 \pm 1.6$ & $79 \pm 1.3$ \\
\hline $\begin{array}{l}\text { After induction/ } \\
\text { Before treatment }\end{array}$ & $79 \pm 1.5^{\mathrm{ns}}$ & $360 \pm 4.1^{* * *}$ & $383 \pm 4.2^{* * *}$ & $385 \pm 3.4^{* * *}$ & $391 \pm 3.6^{* * *}$ & $390 \pm 3.5^{* *}$ \\
\hline $\begin{array}{l}\text { After treatment } \\
\text { 1st day }\end{array}$ & $82 \pm 1.9^{\mathrm{ns}}$ & $372 \pm 3.5^{\mathrm{ns}}$ & $355 \pm 3.4^{\mathrm{ns}}$ & $375 \pm 4.2^{\mathrm{ns}}$ & $374 \pm 4.1^{\mathrm{ns}}$ & $337 \pm 3.8^{\mathrm{ns}}$ \\
\hline 3rd day & $85 \pm 1.3^{\mathrm{ns}}$ & $390 \pm 2.8^{\mathrm{ns}}$ & $320 \pm 3.8^{\mathrm{ns}}$ & $350 \pm 3.5^{\mathrm{ns}}$ & $361 \pm 3.5^{\mathrm{ns}}$ & $290 \pm 2.6^{\mathrm{ns}}$ \\
\hline 7th day & $81 \pm 2.4^{\mathrm{ns}}$ & $408 \pm 4.6^{\mathrm{ns}}$ & $290 \pm 2.7^{\mathrm{ns}}$ & $338 \pm 4.4^{\mathrm{ns}}$ & $330 \pm 3.9^{\mathrm{ns}}$ & $205 \pm 3.8^{*}$ \\
\hline 14th day & $83 \pm 2.1^{\mathrm{ns}}$ & $415 \pm 4.3^{\mathrm{ns}}$ & $285 \pm 3.2^{*}$ & $315 \pm 3.3^{\mathrm{ns}}$ & $297 \pm 2.4^{*}$ & $141 \pm 2.4^{* *}$ \\
\hline 21st day & $85 \pm 1.8^{\mathrm{ns}}$ & $430 \pm 3.5^{*}$ & $320 \pm 2.9^{\mathrm{ns}}$ & $300 \pm 2.8^{*}$ & $280 \pm 2.7^{*}$ & $92 \pm 1.7^{* * *}$ \\
\hline All
\end{tabular}

All values presented as Mean \pm SEM ( $n=6)$. MFM-Metformin, $p<0.05^{*}, p<0.01^{* *}, p<0.001^{* * *}$, ns -non significant. After induction compared with before induction and after treatment compared with before treatment of respective groups.

Effect of Coumarins derivatives on Blood glucose (mg/dl) levels in oral glucose administered (2 $\mathrm{gm} / \mathrm{kg}$ ) rats (Oral glucose tolerance test-OGTT). Prior to glucose administration the FBG levels in all group animals was normal, but after 30 min of glucose load significantly increases was observed. The control group animals exhibit slight decrease in glucose level after 60 and $120 \mathrm{~min}$ but not significant. The rise in blood glucose levels at 30 min due to glucose load not controlled by all the 
three compounds of coumarin derivatives. But after 60 and $120 \mathrm{~min}$ there is slight reduction in blood glucose was observed but not significant. The standard drug MFM given animals also exhibit increase in blood glucose after $30 \mathrm{~min}$ but after 60 and 120 min significant reduction in blood glucose were observed. At end of 120 min blood glucose was almost normal in standard drug given group. All values depicted in Table 3.

Table-3: Effect of Coumarins derivatives on oral glucose tolerance in normal rats.

\begin{tabular}{|c|c|c|c|c|c|}
\hline $\begin{array}{l}\text { Group } \\
\text { Treatment }\end{array}$ & Control & Compound I & Compound II & Compound III & $\begin{array}{l}\text { MFM } \\
100 \mathrm{mg} / \mathrm{kg}\end{array}$ \\
\hline $0 \mathrm{~min}$ & $79 \pm 1.5$ & $80 \pm 1.8$ & $82 \pm 1.3$ & $78 \pm 0.9$ & $80 \pm 1.1$ \\
\hline $30 \mathrm{~min}$ & $148.2 \pm 1.3^{* * *}$ & $148.2 \pm 1.3^{* * *}$ & $146.3 \pm 1.0^{* * *}$ & $140.5 \pm 1.5^{* * *}$ & $138.8 \pm 1.5^{* * *}$ \\
\hline $60 \mathrm{~min}$ & $136.1 \pm 1.8^{* * *}$ & $118.3 \pm 1.4^{* * *}$ & $118.2 \pm 1.5^{* * *}$ & $115.2 \pm 1.4^{* * *}$ & $95.5 \pm 1.0^{*}$ \\
\hline $120 \mathrm{~min}$ & $128.3 \pm 0.7^{* *}$ & $103.4 \pm 2.2^{*}$ & $105.3 \pm 1.6^{*}$ & $101.1 \pm 1.0^{*}$ & $78.2 \pm 1.0 \mathrm{~ns}$ \\
\hline
\end{tabular}

\section{Effect of Coumarins derivatives on lipid profile, total protein and calcium levels in experimental animals}

The serum levels of total cholesterol and triglycerides was significantly $(\mathrm{p}<0.001)$ high but HDL was significantly $(\mathrm{p}<0.001)$ low in diabetic group when compared to normal group. Coumarin derivatives I, II and III treatment reduces the total cholesterol levels, the significant level was $(p<0.01)$, $(\mathrm{p}<0.05)$ and $(\mathrm{p}<0.05)$ respectively. Standard drug treatment significantly $(\mathrm{p}<0.001)$ reduces total cholesterol levels compare to diabetic control group animals. Coumarin derivatives I, II and III treatment does not reduces significantly the triglycerides levels compare to diabetic control group. Standard drug treatment significantly $(\mathrm{p}<0.001)$ reduces triglycerides level compare to diabetic control group animals. HDL Cholesterol level was significantly $(\mathrm{p}<0.001)$ low in diabetic animals compare to normal control group. Coumarin derivatives I, II and III treatment does not increases significantly the HDL Cholesterol levels compare to diabetic control group. But Standard drug treatment significantly $(p<0.001)$ increases HDL Cholesterol levels compare to diabetic control group animals. Total protein and calcium levels was significantly $(p<0.001)$ low in diabetic animals compare to normal control group. Coumarin derivatives I, II and III treatment does not increases significantly the total protein and calcium levels compare to diabetic control group. But Standard drug treatment significantly $(\mathrm{p}<0.001)$ increases total protein and calcium levels compare to diabetic control group animals. All values depicted in Table 4.

Table-4: Effect of coumarin derivatives on lipid profile, total protein and calcium levels in experimental

\begin{tabular}{|l|l|l|l|l|l|l|}
\hline \multicolumn{1}{|c|}{ Group } & Control & $\begin{array}{l}\text { Diabetic } \\
\text { control }\end{array}$ & $\begin{array}{l}\text { Compound } \\
\text { I }\end{array}$ & $\begin{array}{l}\text { Compound } \\
\text { II }\end{array}$ & $\begin{array}{l}\text { Compound } \\
\text { III }\end{array}$ & $\begin{array}{l}\text { MFM 100 } \\
\text { mg/kg }\end{array}$ \\
\hline $\begin{array}{l}\text { Total Cholesterol } \\
(\mathrm{mg} / \mathrm{dl})\end{array}$ & $87.78 \pm 1.4$ & $149.5 \pm 3.3^{* * *}$ & $114.6 \pm 2.2^{* *}$ & $120.4 \pm 3.2^{*}$ & $125.2 \pm 2.5^{*}$ & $83.9 \pm 2.0^{* * *}$ \\
\hline $\begin{array}{l}\text { Triglycerides } \\
(\mathrm{mg} / \mathrm{dl})\end{array}$ & $88.32 \pm 1.6$ & $124.5 \pm 3.3^{* * *}$ & $124.9 \pm 1.9 \mathrm{~ns}$ & $116 \pm 3.2^{\mathrm{na}}$ & $\begin{array}{l}129.0 \pm 2.9 \\
\mathrm{~ns}\end{array}$ & $93.0 \pm 3.1^{* * *}$ \\
\hline $\begin{array}{l}\text { HDL Cholesterol } \\
(\mathrm{mg} / \mathrm{dl})\end{array}$ & $25.88 \pm 3.0$ & $16.7 \pm 2.3^{* * *}$ & $15.3 \pm 2.7^{\mathrm{ns}}$ & $17.6 \pm 2.2^{\mathrm{ns}}$ & $14.4 \pm 2.1^{\mathrm{ns}}$ & $29.3 \pm 1.8^{* * *}$ \\
\hline $\begin{array}{l}\text { Total protein } \\
\text { (g/dl) }\end{array}$ & $8.637 \pm 0.7$ & $3.8 \pm 0.4^{* * *}$ & $5.8 \pm 0.4^{\mathrm{ns}}$ & $5.6 \pm 0.4^{\mathrm{ns}}$ & $6.1 \pm 0.5^{\mathrm{ns}}$ & $8.7 \pm 0.9^{* * *}$ \\
\hline Calcium (g/dl) & $10.56 \pm 0.4$ & $5.9 \pm 0.5^{* * *}$ & $5.7 \pm 0.3^{\mathrm{ns}}$ & $6.6 \pm 0.2^{\mathrm{ns}}$ & $5.6 \pm 0.4^{\mathrm{ns}}$ & $9.4 \pm 0.5^{* * *}$ \\
\hline
\end{tabular}

All values presented as Mean \pm SEM $(n=6)$. MFM-Metformin, $p<0.05^{*}, p<0.01^{* *}, p<0.001^{* * *}$, ns -non significant.

Diabetic control group compared with normal control and treatment groups compared with diabetic control

groups.

DM occupies now one of the main causes of serious malady in 21 Century. The cause for DM is lifestyle, genetic etc. Biochemical variations occurs mainly carbohydrate, protein and lipid metabolism. A change in levels or activity of protein, lipids, glucose, insulin and elements like calcium occurs. This entire biochemical changes occurs because of altered structure \& function of pancreas, enzymes activity and resistance development to hormones. A high TC and TG attributed to stop cholesterol catabolism, lack of insulin or adipose tissue releases fatty acids by lipolysis. The rise in HDL-cholesterol level used to wash out the excessive cholesterol from body is considerably reduced in DM. The 
improvement in HDL-cholesterol complemented by improved breakdown of VLDL and placing of TG in the central of HDL with cholesterol. This lipid is not significantly normalized by coumarin derivatives may be due to its not acting on enzymes involved in lipid metabolism. This does not prevent development of neuropathy, atherosclerosis and cardiovascular complications associated with the diabetes. An abnormality in proteins glycation nonenzymatically is also atherogenic, excessive breakdown of proteins further cause's micro vascular issues. Coumarin derivatives significantly does not prevents abnormal breakdown of proteins and not normalizes total protein. Calcium is an element essential for the homeostasis. Calcium level in body regulated by hormones by acting on renal, digestive and skeletal systems. If changes in blood calcium levels affects insulin release by pancreas, glucose sensitivity, bones and blood pressure.

The rise in oxidative stress and its squealed are widely accepted in diabetes. Several studies have drawn attention antioxidants may be a good strategy to reduce diabetes also related complications. An evaluation of the action of alloxan, a pancreatic beta cell cytotoxin has shown physiological and biochemical disorder leads to diabetic state. Alloxan (150 mg/kg) demonstrated hyperglycemia due to metabolic stress, altered insulin secretion \& due to a progressive oxidative stress. Twenty-one days treatment with coumarin derivatives not significantly corrected the protein, lipid and carbohydrate metabolism. It does not normalize the levels of blood glucose, total protein, calcium and lipid profile, also the structure \& functions of pancreas. Coumarin derivatives do not significantly contribute or shown Antidiabetic activity. All three compounds of coumarin derivatives possess very poor antidiabetic property.

\section{CONCLUSION}

Abnormal levels of blood glucose, lipid profile, total protein and calcium in alloxan induced diabetic rats where not significantly normalized by coumarin derivatives. Hence all three title compounds possess very poor antidiabetic property. The electron releasing groups on the aromatic ring will enhance the activity. Hence the structural modification on the aromatic ring may require for enhancing antidiabetic activity.

\section{AUTHOR CONTRIBUTIONS}

All authors contributed for designing, collection, analysis and interpretation of data. All together written the research article and made decision to submit to this journal. All the authors are entitled to be an author as per the international committee of medical journal editors (ICMJE) requirements/guidelines.

\section{FUNDING}

There is no funding for this research work.

\section{CONFLICTS OF INTEREST}

The authors don't have any conflicts of interest in this research work.

\section{ACKNOWLEDGMENTS}

Authors are thankful to the principal, KLE College of Pharmacy, Hubballi for providing laboratory facility to conduct this research work.

\section{REFERENCE}

1. Sada NM, Tanko Y, Mabrouk MA. (2013). Modulatory role of soya beans supplement on lipid profiles and liver enzymes on alloxaninduced diabetic Wistar rats: Eur J Exp Bio, 3(2):62-7.

2. Lyra R, Oliveira M, Lins D, Cavalcanti N. (2006). Prevention of type 2 diabetes mellitus: Arquivos Brasileiros de Endocrinologia \& Metabologia, 50(2):239-49.

3. Rajaei Z, Hadjzadeh MAR, Moradi R, Ghorbani A, Saghebi A. (2015). Antihyperglycemic and antihyperlipidemic effects of hydroalcoholic extract of Securigera securidaca seeds in streptozotocin-induced diabetic rats: Adv. Biomed. Res, 4(33):1-15.

4. Global report on diabetes. World health organization; 2016.

5. Wright JR, Abraham C, Dickson BC, Yang H, Morrison CM. (1999). Streptozotocin doseresponse curve in tilapia, a glucose-responsive teleost fish: Gen. Comp. Endocrinol, 114:431-40.

6. C. C. Chiang, M. J. Cheng, C. F. Peng, H. Y. Huang, and I. S.Chen. (2010). "Anovel dimeric coumarin analog and antimycobacterial constituents from Fatoua pilosa," Chemistry and Biodiversity, 7(7):1728-36.

7. Y. Kashman, K. R. Gustafson, R. W. Fuller et al., (1992). "The calanolides, a novel HIV-inhibitory class of coumarin derivatives from the tropical rainforest tree, Calophyllum lanigerum," Journal of Medicinal Chemistry, 35(15):2735-43.

8. N. B. Piller. (1975). "A comparison of the effectiveness of some anti-inflammatory drugs on thermal oedema," British Journal of Experimental Pathology, 56(6):554-60.

9. M. I. Yusupov and G. P. Sidyakin. (1975). "Fraxidin and isofraxidin from Artemisia scotina," Chemistry of Natural Compounds, 11(1):94.

10. Verma A, Dewangan P, Kesharwani D, Kela SP. (2013). Hypoglycemic and hypolipidemic activity of scopoletin (coumarin derivative) in streptozotocin induced diabetic rats. Int J Pharm Sci Rev Res, 22(1):79-83. 
11. Anandan R, Jayakar B, Karar B, Babuji S, Manavalan R, Kumar RS, et al. (2009). Effect of ethanol extract of flowers of Vitex trifolia Linn. On CCL4 induced hepatic injury in rats. Pak J Pharm Sci, 22:391-4.

12. Wahyuono S, Alam G, Ikawati Z, Timmerman $H$, Maeyama K. (2009). Antiasthmatic compounds isolated from antiasthmatic "JAMU" ingredient legundi leaves (Vitex trifolia L.). Sci Pharm, 77:192-3.

13. Natheer SE, Sekar C, Amutharaj P, Rahman MS, Khan KF. (2012). Evaluation of antibacterial activity of Morinda citrifolia, Vitex trifolia and Chromolaena odorata. Afr J Pharm Pharmacol, 6:783-8.

14. Goverdhan P, Diwakar B. (2009). Antinociceptive and anti-inflammatory effects of the leaf extract of Vitex trifolia Linn. In experimental animals. Ethno.bot. Leaf, 13:65-72.

15. Venugopala KN, Rashmi V, Odhav B. (2013). Review on natural coumarin lead compounds for their pharmacological activity. BioMed research international, 13:1-14.

16. Liang Lei, Yong-bo Xue, Zhong Liu. (2015). Coumarin derivatives from Ainsliaea fragrans and their anticoagulant activity. Nature, Scientific reports 5, 13544:1-9.

17. Tiwari N, Thakur J, Saikia D, Gupta MM. (2013). Antitubercular diterpenoids from Vitex trifolia. Phytomedicine, 20:605-10.

18. Hossain MM, Paul N, Sohrab MH, Rahman E, Rashid MA. (2001). Antibacterial activity of Vitex trifolia. Fitoterapia, 72:695-7.

19. Ronad, P., Hunashal, R., Darbhamalla, S., \& Maddi, V. (2008). Synthesis and Evaluation of Antiinflammatory and Analgesic Activities of a Novel Series of Substituted-N-(4-methyl-2-oxo2H-chromen-7-yl) benzamides. Arzneimittelforschung, (Drug Research), 58(12):641-46.

20. Surana SJ, Gokhale SB, Jadhav RB, Sawant RL, Wadekar JB. (2008). Antihyperglycemic activity of various fractions of Cassia auriculata in alloxan diabetic rats. Ind J Pharm Sci, 70(2):22729.

21. Fard MH, Naseh G, Lotfi N, Hosseini SM, Hosseini M. (2015). "Effects of aqueous extract of turnip leaf (Brassica rapa) in alloxan-induced diabetic rats": Avicenna Journal of Phytomedicine, 5(2):148-56.

22. Bamidele 0 , Arokoyo DS, Akinnuga AM, Oluwarole AO. (2014). Antidiabetic effect of aqueous extract of Basella alba leaves and metformin in alloxan-induced diabetic albino rats: African journal of Biotechnology, 13(24):2455-58.

23. Suryawanshi NP, Bhutey AK, Nagdeote AN, Jadhav AA, Manoorkar GS. (2006). Study of lipid peroxide and lipid profile in diabetes mellitus: Indian J Clin Biochem, 21(1):126-30.

24. Abbate SL, Brunzell JD. (1990). Pathophysiology of hyperlipidemia in Diabetes Mellitus: J of Cardiovascular Pharmacology, 16(9):1-7.

25. Arora M, Koley S, Gupta S, Sandhu JS. (2007). A study on lipid profile and body fat in patients with diabetes mellitus: Anthropologist, 9(4):295-8.

26. Moller N, Nair KS. (2008). Diabetes and protein metabolism: Diabetes, 57(1):3-4.

27. Friel K. (2004). The Effects and Interactions of Vitamin D Deficiency, Calcium and Parathyroid Hormone on Physical Concerning the Elderly: A Review. J Geriatr Phys Ther, 27(1):30-34.

28. Jeedi NM, Koti BC. (2017). Antidiabetic and antihyperlipidemic activity of Premna latifolia extract in streptozotocin-induced diabetic rats: International Journal of Research in Pharmaceutical Sciences, 8(4):708-15.

29. Barham D, Trinder P. (1972). An improved colour reagent for the determination of blood glucose by the oxidase system: Analyst, 97(151):142-5.

30. Tietz NW. Ashwood C editor. 1999. Textbook of clinical chemistry. Edn 3, W B Saunders, 826-35.

31. Fossati P, Prencipe L. (1982). Serum triglycerides determined colorimetrically with an enzyme that produces hydrogen peroxide: Clin Chem, 28(10):2077-80.

32. McGowan MW, Artiss JD, Strandbergh DR, Zak B. (1983). A peroxidase-coupled method for the colorimetric determination of serum triglycerides: Clin Chem, 29(3): 538-42.

33. Rifai ND, Warnick GR, Dominiczak MH. (1997). Handbook of Lipoprotein Testing. Edn 2, AACC Press, Washington, 99-114.

34. Michael ML. (1978). The Measurement of Total Serum Proteins by the Biuret Method: Annals of Clinical and Laboratory Science, 8(2);106-10.

35. Morgan BR, Artiss JD, Zak B. (1993). Calcium determination in serum with stable alkaline Arsenazo III and triglyceride clearing: Clinical Chemistry, 39(8):1608-12. 